in which detailed information, interesting physical data, and extremely valuable advice on practice are given. Maximum permissible levels of radiation; protection against ionizing radiation particularly from X-ray apparatus; classification of radioisotopes; requirements for radiochemical laboratories; monitoring; storage and disposal of active materials and waste; emergency procedures and fire precautions are some of the topics discussed. An extensive bibliography is also provided. For other university departments which have yet to establish their own radiation safety committee and produce their own regulations, the Code should prove an excellent model to copy.

\section{U.K. Library Telex Directory}

THE second edition of the Library Telex Directory, compiled from 700 questionnaires issued to organizations known to have access to telex and reported to possess library or information services, contains entries for 400 libraries compared with 131 in the first edition in 1960 (Pp. 24. London: The Library Association, 1962. 8s.; L.A. members 6s.). Some entries are qualified by restrictions. Some notes on the use of telex in libraries which preface the Directory stress the importance of stating the urgeney of a request, of not economizing in words at the expense of elarity, of sending brief acknowledgments of action taken or to be taken, and of spacing loan requests on the paper roll and including name and address with each separate item.

\section{The Quarter-Inch Map of Great Britain}

February 1 saw the completion of the Ordnance Survey's Fifth Series of the Quarter-Inch Map of Great Britain when the last two sheets were published. Hence the whole of Britain is now covered by this post-war series begun in 1957. The quarter-inch 'travellers' map, as it could be called-for here lies its greatest utilityowes its beginning to the War Office and the Ordnance Survey. It was begun in 1859 , but its publication was delayed for almost twenty-five years owing to the all-out effort of the engravers of the day to complete the one-inch map then on hand; moreover, its sale to the public was not until 1887. In order to conform with continental practice and the requirements of air navigation the scale of the Quarter-Inch Map of Great Britain is, in fact, now $1: 250,000$ and not $1: 253,440$. As with previous editions, the Fifth Series has been derived from the one-inch map, in this case the post-war Seventh Series. Compared with the Quarter-Inch Fourth Edition, the amount of detail on the Fifth Series has been reduced in the knowledge that there exists an up-to-date one-inch map for more detailed reference. Relief is shown by hypsometrical or layer tints and contour lines, with the addition of hill shading to give a more readable picture of the ground. Special effort has been made to make the map useful to the motorist by clearly defining Motorways, Class I and II roads and dual carriageways.

\section{The Royal Society and Nuffield Foundation Common- wealth Bursaries Scheme}

Awards under the Royal Society and Nuffield Foundation Commonwealth Bursaries Scheme have been made as follows: Dr. Madge G. Adam, university demonstrator in astronomy, Oxford, to assist her to visit Mount Stromlo Observatory for a year from August in order to use the 74-in. telescope there for a study of magnetic stars in the southern sky; Dr. U. Aswathanarayana, reader in geology, Andhra University, to enable him to familiarize himself with recent advances in methodology and experimental techniques of radioactivity methods of dating, at Oxford, from April until September; Dr. N. Collis-George, associate professor of soil science, University of Sydney, to enable him to become acquainted at first-hand with the theoretical and experimental methods of describing the movement of water through soils, at Cambridge, from July until December; Dr. P. J. Grubb, university demonstrator in botany, Cambridge, to enable him to investigate the sodium/potassium relations of the Atriplex spp. growing in the arid areas near Adelaide, from April until October; Dr. J. R. Richards, Fellow in the Department of Geophysics, Australian National University, to assist him to gain further experience in the measurement of lead isotope ratios and to extend his experience in the arts of isotope geology and geochronology at the University of British Columbia and the University of Toronto, for about eight months from March; Dr. C. G. Winder, associate professor of geology, University of Western Ontario, to enable him to gain experience of studying conodonts at the University College of Swansea and to study the type exposures of the Ordovician, Silurian and Devonian systems of rocks which occur in Wales and Devon, from April until September 1963.

\section{Announcements}

Mr. J. West has been awarded the recently instituted City and Guilds of London Institute's Prince Philip Medal. This award, which is made annually, is restricted to persons under 40 years of age who have "travelled the City and Guilds path" and passed one of the Institute's examinations. Mr. West, when assistant manager of P. and O. Orient Management, Ltd., was the designer of the 45,000-ton passenger liner Canberra.

A MEMBERs' day incorporating the annual general meeting, arranged by the National Vegetable Research Station Association, will be held on March 12. Further information can be obtained from the Secretary, National Vegetable Research Station, Wellesbourne, Warwick.

THE fourteenth annual meeting of the Tissue Culture Association will be held at the Somerset Hotel, Boston, during May 27-30. Three of the six sessions will be devoted to a symposium on "Metabolic Control Mechanisms in Animal Cells". Further information can be obtained from Prof. P. Goldhaber, Harvard School of Dental Medicine, 188 Longwood Avenue, Boston, Mass.

A CONFEREnce on "Semiconductor Power Controls", arranged by Texas Instruments, Ltd., will be held in Bedford on March 18. Subjects under discussion will include: basic SCR circuit considerations; gate-controlled switches; proportional power controls; motorcontrol circuits; d.c. motor-control circuits; a.c. motorcontrol circuits; power supplies. Further information can be obtained from Mr. W. A. Yates, Texas Instruments, Ltd., Manton Lane, Bedford, England.

AN international symposium on "Aqueous Reprocessing Chemistry of Nuclear Fuels", organized by the European Company for Chemical Processing of Irradiated Fuels and the Organization for Economic Co-operation and Development, European Nuclear Energy Agency, is to be held in Brussels during April 23-26. Further information can be obtained from the Organization for Economic Co-operation and Development, European Nuclear Energy Agency, 38 Boulevard Suchet, Paris 16 ème.

Tне jubilee meeting of the British Ecological Society will be held at Queen Elizabeth College, London, during March 28-31. The programme has been divided into six sessions: ecology and conservation; Quaternary ecology; the history of ecology in Britain; experimental and autecological studies; production ecology; the community concept. Prof. W. H. Pearsall will give the Jubilee Address, entitled "The Development of Ecology in Britain", on March 29. Further information can be obtained from A. Macfadyen, Department of Zoology, University College, Swansea, or from Dr. P. J. Newbould, Department of Botany, University College, Gower Street, London, W.C.1. 